Research Article

\title{
Study on Seroprevalence and Associated Factors of Bovine Brucellosis in Selected Districts of Afar National Regional State, Afar, Ethiopia
}

\author{
Wossene Negash $(\mathbb{D})$ and Teshager Dubie $(\mathbb{D})$ \\ College of Veterinary Medicine, Samara University, P.O. Box 132, Samara, Russia \\ Correspondence should be addressed to Wossene Negash; tsgaw13@gmail.com
}

Received 8 May 2020; Accepted 21 February 2021; Published 3 March 2021

Academic Editor: Sumanta Nandi

Copyright (C) 2021 Wossene Negash and Teshager Dubie. This is an open access article distributed under the Creative Commons Attribution License, which permits unrestricted use, distribution, and reproduction in any medium, provided the original work is properly cited.

\begin{abstract}
Bovine brucellosis is among the top five diseases primarily threatening both public health and livestock economy. Available data are limited to central and highland areas of the country leaving documented literature on the disease in cattle to be found hardly in pastoral and agropastoral regions of the country. As a result, the magnitude and extent of the disease remained to be investigated. A cross-sectional study design was conducted on local Afar cattle aged six months and above from February 2017 to January 2019 in selected districts of Afar region. Technically, study districts and kebeles were selected purposively whereas simple random sampling technique was applied to select cattle owners and individual animals for sample collection. An average of $8 \mathrm{ml}$ whole blood was drawn of jugular vein into plain vacutainer tube using sterile needle. Using Thrusfield formula, a total of 420 blood samples were collected. The sera were tested by RBPT and CFT tests for detection of Brucella antibodies. Data were analyzed using Stata v14.0. Of the 420 sera tested by RBPT, 50 were positive for Brucella antibodies providing an overall animal level prevalence of $11.9 \%$ and those RBPT positive sera were further retested by specific and sensitive confirmatory CFT test and 24 of the retested samples had come positive for the disease providing an overall individual animal seroprevalence of $5.7 \%$ over the three districts. Of the 3 associated factors (sex, age, and district) considered, only sex had significantly associated $(P<0.05: 0.036)$ with the disease. To estimate the strength of sex impact, odds ratio was generated using bivariate and multivariate logistic regression analyses with $95 \% \mathrm{CI}$ and $P<0.05$ providing OR of 2.484 (1.061-5.815) and 2.514 (1.041-6.07), respectively. Hence, the computations revealed that male cattle were 2.484 and 2.514 times more likely at higher risk for the disease as compared to their female counterparts.
\end{abstract}

\section{Introduction}

Human population depends on the domestic animals for production of meat, fat, milk, dairy products, transport, draft power, eggs production, fertilizers, and fibers [1]. In Ethiopia, more than $80 \%$ of the population is dependent on agriculture in which livestock plays a dominant role [2]. Being the major livestock component, cattle have played a crucial role throughout human the history providing draft power, milk, and meat for human consumption since domestication $[3,4]$.

Bovine brucellosis is considered the world's most common bacterial zoonosis [5] and highly contagious and economically important public disease. FAO, WHO, and OIE considered the disease as one of the most wide spread zoonoses in the world [6] causing economic, veterinary, and public health consequences in the developing countries $[5,7]$. Within sub-Saharan Africa, many of the known infectious diseases commonly occur and are poorly controlled both in livestock and in human population. Public funds rose for the control of such infectious diseases progressively decreased over the last 20 years [8]. Brucellosis is widely spread within African countries [9] and considered by the World Health Organization as being responsible for more sickness, misery, and economic loss than any other zoonosis [10]. Bovine brucellosis is listed among the top five zoonotic diseases in Ethiopia [11].

Bovine brucellosis affects a number of species including humans, ruminants, swine, rodents, canines, and marine 
mammals with global distributed. Bovine brucellosis is usually caused by Brucella abortus and occasionally by Brucella melitensis and Brucella suis [12]. Biologically, Brucella species are facultative intracellular, Gram-negative, flagellated, nonmotile, oxidase positive, catalase positive, urease positive, non-spore-forming, noncapsulated, and partially acid-fast coccobacilli that lack capsules, endospores, or native plasmids. They cannot survive most disinfectants. Under appropriate conditions, Brucella can survive outside the host for extended period of time. They can remain viable in carcass and tissues for 6 months at $0^{\circ} \mathrm{C}$, up to 125 days in soil and 1 year in feces [13]. Pasteurization effectively kills Brucella in milk [14].

Brucellosis is mainly transmitted through inhalation, abraded skin, or ingestion of organisms along with contaminated food and drinks. High numbers of organisms are shed in urine, milk, vaginal discharge, semen, and delivery discharges of infected animals $[15,16]$.

The disease is presented as an acute or persistent febrile illness with a diversity of clinical manifestations [17] having incubation period between 14 and 120 days [18]. Bovine brucellosis is clinically characterized by late term abortion, neonatal losses, infertility, reduced milk production, and death of full-term calves [19-21].

Brucellosis causes both direct and indirect losses: indirect losses include morbidity, stunting, reduced fertility, decreased milk production, lowered sale value of infected cows, lack of access to markets, restrictions of international trade of live animals and their products, disruption of local markets and direct losses include abortion, neonatal death, replacement costs, treatment costs, labor costs, emergency slaughtering of the infected animals, and stillbirths [22-25].

Bovine brucellosis has been eradicated in most developed countries through the implementation of several extensive control programs, whereas developing countries continued to experience an increasing trend of the disease because of lack of resources and coordinated control programs. Moreover, in sub-Saharan Africa, increased pastoralism and intensification of commercial livestock farms have contributed to disease impact [26].

Bovine brucellosis remains under diagnosed and underreported in many developing countries [27] though an important bacterial disease among livestock and people in sub-Saharan Africa [28]. Epidemiology and preventive measures of brucellosis in livestock and humans are not well understood, and such information is inadequate particularly in sub-Saharan Africa [6, 8, 29].

A number of serological surveys have been documented so far indicating that brucellosis is an endemic disease in urban, periurban, highland and lowland, extensive and intensive farming, small holder farms, and ranches of the country [29-31].

Available reports reaffirmed that brucellosis is an endemic disease in Ethiopia, and researchers have established its prevalence rate in cattle in different regions of the country [32]. In the last two decades, serological studies have been reported by different scholars in Ethiopia. Accordingly, 39\% by Mayer [33] in Western Ethiopia, 8.2\% by Bayleyegne [34] in central part of the country, $22 \%$ by Tariku [35] in a dairy farm in Northeastern Ethiopia, $8.1 \%$ by Yilkal [36] in dairy farms in and around Addis Ababa, 11\%-15\% by Tekelye et al. [37], in dairy farms and ranches in southwestern Ethiopia, $7.7 \%$ by Mekonnen et al. [38] in Tigray region, $0.14 \%$ by Taddesse [39] in north Gondar zone, $0.77 \%$ by Tadele [40] in Southwestern Ethiopia, $1.11 \%$ by Yohannes et al. [41] in Addis Ababa and Sululta abattoir, 2.46\% by Kassahun et al. [42] in Sidama zone of southern Ethiopia, $22 \%$ by Sintaro [43] in dairy herd of Cheffa state farm, and $5 \%$ by Berhe et al. [44] and Ibrahim et al. [45] in cattle under crop-livestock mixed farming were documented, respectively.

A study conducted by Hunduma and Regassa [46] reported the occurrence of bovine brucellosis in pastoral and agropastoral areas of East Shoa Zones of Oromia supporting the presence of the disease in pastoral and agropastoral areas of Ethiopia. Moreover, Dinka and Chala [29] reported that the prevalence of Bovine brucellosis in pastoral areas was found to be higher than agropastoral areas. However, those reports on cattle brucellosis were mainly conducted in central and northern Ethiopia and do not provide an adequate epidemiological picture of the disease in different agroecological zones and livestock production systems of the country [47], suggesting that limited studies on bovine Brucellosis have been done far in pastoral and agropastoral areas of East Africa [48, 49]. According to Dinka and Chala [29], limited data are available on cattle brucellosis in pastoral and agropastoral areas of Ethiopia despite the presence of large population of cattle. In addition to indicated scarcity of studies in pastoral areas, cattle herders in pastoral areas are in close contact with their animal, consume raw milk, and handle aborted materials further compounding brucellosis problems according to Omer et al. [50].

In general, it could be inferred that the extent and magnitude of bovine brucellosis in pastoral and agropastoral areas in general and Afar pastoral and agropastoral areas in particular have not been studied yet. Therefore, the objectives of the present study were to determine the prevalence of bovine brucellosis in selected districts of the region and to assess and identify associated factors with the disease.

\section{Materials and Methods}

The study was conducted in three selected districts of Afar region, namely, Dubti, Asaita, and Chifra. All are situated in zone one of Afar region. The Afar region is one of the nine federal states of Ethiopia located in the northeastern part of the country. The region is geographically located between $39^{\circ} 34^{\prime}$ and $42^{\circ} 28^{\prime}$ East Longitude and $8^{\circ} 49^{\prime}$ and $14^{\circ} 30^{\prime}$ North Latitude. The region comprises 5 administrative zones, 32 districts and 331 kebeles, 28 towns, and 401 rural and urban kebeles [2].

2.1. Study Design. A cross-sectional study design was applied to determine the seroprevalence of bovine brucellosis and associated risk factors in the selected study sites. 
2.2. Study Population. All indigenous Afar cattle aged 6 months and above reared by pastorals and agropastorals in the selected sites were used for the study.

\subsection{Sampling Technique and Sample Size Determination.} Both randomized and purposive sampling techniques were applied for selection of study animals (cattle) and study areas. While study zone, districts, and kebeles were chosen purposively, households and study units/individual cattle were selected using simple random sampling technique. As no previous study was conducted on bovine brucellosis in cattle found in the selected areas, the present study has considered 50\% expected prevalence, 95\% confidence level, and $5 \%$ absolute precision or marginal error. Based on these assumptions, the total number of animals to be included in the study got determined using the Thrusfield [51] formula:

$$
n=\frac{1.962 \times P_{\exp } \times\left(1-P_{\exp }\right)}{d^{2}}
$$

where $n=$ required sample size, $d=$ desired absolute precision, and $P_{\text {exp }}=$ expected prevalence $(50 \%)$.

Based on the formula, the total sample size was computed to be 384 cattle to be selected from all three districts. To minimize chance and increase precision of the outcome, the total number of study animals was increased to 420 . Proportionally, a total of 128, 130, and 162 were collected from Asaita, Dubti, and Chifra districts, respectively, based on density of cattle population in the districts.

\section{Methodology}

An average of $8 \mathrm{ml}$ whole blood was drawn from jugular vein of each 420 cattle into labeled plain vacutainer test tubes using 21 gauge needles. Sera were separated from the blood into labeled cryogenic vials. Each sample container was labeled with animal ID, age, site, and sex of every animal. Labeled sera were stored at $-20^{\circ} \mathrm{C}$ prior to serological analysis.

3.1. Serological Tests. Both the screening and confirmatory tests were carried out at the National Veterinary Institute, Ethiopia.

3.2. Screening Test or Rose Bengal Plate Test (RBPT). Each serum was tested against Brucella agglutinin antigen using sensitive RBPT technique based on the protocol of the OIE $[52,53]$.

\subsection{Confirmatory Test by Complement Fixation Test (CFT).} Those sera clearly detected positive by RBPT were further retested using the more specific confirmatory CFT according to the procedures recommended by OIE [53] using standard Brucella abortus antigen to detect the presence of antiBrucella antibody in the sera.
3.4. Questionnaire Survey. Semistructured questionnaire were administered to selected cattle owners following verbal consent on the need of the study. For each animal sampled, questionnaire data were collected concerning age, sex, and study site to analyze the impact of these variables on the occurrence of the disease.

3.5. Data Management and Analysis. Relevant data were organized, coded, and entered into Microsoft Excel sheet. Organized data were transferred to Stata v14.0 [54]. Descriptive and chi-squared statistics and logistic regression analyses were employed during data analysis. Descriptive statistics will be done to determine prevalence of the disease and other frequencies. The chi-squared $\left(\chi^{2}\right)$ statistics will be employed to determine the association between the associated factors and the disease. Both bivariate and multivariate logistic regression analyses were computed to determine the degree of strength between those associated factors and the disease (brucellosis).

\section{Results}

Descriptive statistics was employed to calculate prevalence and percentages of associated factors (sex, age, and district) with respect to the test results as summarized in (Table 1). The total number of animals sampled were $420 \quad(n=246$ females and $n=174$ males).

All $(n=420)$ sera were subjected to the screening test (Rose Bengal Plate test-RBPT) against Brucella abortus antigen, and 50 of them have come positive for bovine brucellosis with an overall prevalence of $11.9 \%$ with $95 \%$ CI (8.79-15.015). Those RBPT positive samples were further retested by the more specific confirmatory test of CFT of which only 24 of them were really positive for bovine brucellosis providing an overall prevalence of $5.7 \%$ (Table 2) with 95\% CI (3.48-7.94).

4.1. Logistic Regression. To assess the impact of associated factors on the disease occurrence, chi-square $\left(\chi^{2}\right)$ statistics was computed. Accordingly, only sex $(P<0.05$ : 0.036$)$ was significantly associated with the disease (bovine brucellosis). Further, using 95\%CI and $P<0.05$, unadjusted odds ratio was computed using binary logistic regression separately for each factor (sex, age, and district) to estimate the magnitude each factor could pose on the disease (Table 3). Similarly, adjusted odds ratio (AOR) was also computed simultaneously to determine the real magnitude (without compounding effect) of the factors one on the disease.

Logistic regression computations had vividly revealed that male cattle were 2.484 times more likely at risk for the disease as compared to their female counterparts.

\section{Discussion}

Brucellosis is a disease having drawn attention and concern for it causes public threat and economic losses in the cattle industry [55]. The disease can be diagnosed using several serological tests including rose Bengal test (RBPT), 
TABLE 1: Descriptive variables against the disease (CFT test).

\begin{tabular}{|c|c|c|c|c|}
\hline \multirow{2}{*}{ Variable } & \multirow{2}{*}{ Category } & \multicolumn{2}{|c|}{ CFT } & \multirow{2}{*}{$P$ value } \\
\hline & & Negative (\%) & Positive (\%) & \\
\hline \multirow{3}{*}{ District } & Dubti & $123(94.6)$ & $7(5.4)$ & \multirow{3}{*}{0.644} \\
\hline & Asaita & $118(92.2)$ & $10(7.8)$ & \\
\hline & Chifra & $155(95.7)$ & $7(4.3)$ & \\
\hline \multirow{3}{*}{ Age } & Young & $119(94.4)$ & $7(5.6)$ & \multirow{3}{*}{0.118} \\
\hline & Adult & $175(97.2)$ & $5(2.8)$ & \\
\hline & Old & $102(89.5)$ & $12(10.5)$ & \\
\hline \multirow{2}{*}{ Sex } & Female & $237(96.3)$ & $9(3.7)$ & \multirow{2}{*}{0.036} \\
\hline & Male & $159(91.4)$ & $15(8.6)$ & \\
\hline
\end{tabular}

TABle 2: Prevalence of bovine brucellosis by CFT and RBPT tests.

\begin{tabular}{lccccc}
\hline Test type & Samples tested & Negative samples & Positive samples & Prevalence (\%) & 95\% CI \\
\hline CFT & 420 & 396 & 24 & 5.7 & $3.48-7.94$ \\
RBPT & 420 & 370 & 50 & 11.9 & $8.79-15.015$ \\
\hline
\end{tabular}

TABle 3: Summary of bivariate and multivariate logistic regression analyses.

\begin{tabular}{|c|c|c|c|c|c|c|}
\hline \multirow{2}{*}{ Variable } & \multicolumn{2}{|c|}{ CFT test } & \multicolumn{2}{|c|}{ Binary logistic regression } & \multicolumn{2}{|c|}{ Multivariate logistic regression } \\
\hline & Negative & Positive & COR $(95 \% \mathrm{CI})$ & $P$ value & AOR $(95 \% \mathrm{CI})$ & $P$ value \\
\hline \multicolumn{7}{|l|}{ Age } \\
\hline Young & 119 & 7 & 1 & & 1 & $\mathbf{0}$ \\
\hline Adult & 175 & 5 & $0.486(0.1506-1.567)$ & 0.227 & $0.565(0.173-1.849)$ & 0.345 \\
\hline Old & 102 & 12 & $2(0.759-5.270)$ & 0.161 & $2.509(0.843-7.463)$ & 0.098 \\
\hline \multicolumn{7}{|l|}{ Sex } \\
\hline Female & 237 & 9 & 1 & & & $\mathbf{0}$ \\
\hline Male & 159 & 15 & $2.484(1.061-5.815)$ & 0.036 & $2.514(1.041-6.07)$ & 0.040 \\
\hline \multicolumn{7}{|l|}{ District } \\
\hline Dubti & 123 & 7 & 1 & & 1 & $\mathbf{0}$ \\
\hline Asaita & 118 & 10 & $1.489(0.549-4.041)$ & 0.434 & $1.387(0.499-3.854)$ & 0.530 \\
\hline Chifra & 155 & 7 & $0.794(0.271-2.323)$ & 0.673 & $1.413(0.427-4.668)$ & 0.571 \\
\hline
\end{tabular}

complement fixation test (CFT), ELISA, and others [56]. In the present study, only CFT and RBPT were applied for Brucella antibody detection and accordingly reported $5.7 \%$ and $11.9 \%$ overall individual animal level seroprevalence by CFT and RBPT, respectively. The two tests showed level of degree agreement though the RBPT test was observed to show false positivity. In epidemiological studies, the serial use of two tests is recommended to maximize the accuracy of test results [57] and the most widely used testing scheme. RBT is a highly sensitive test and could easily be applied in field conditions for the screening purpose, whereas CFT is highly specific and sensitive usually test used as a confirmatory test for detection of Brucella antibodies in the diagnosis of bovine brucellosis [55, 58].

False positive serological reactors in RBT could be due to cross-reactions with smooth lipopolysaccharide (S-LPS) antigens of other bacteria. As there has never been a history of vaccination in all of our study districts, seropositivity in this case was therefore only due to natural infection. The RBPT test result of the current study has revealed an overall prevalence of $11.9 \%$ in cattle over 3 districts in Afar region lying within the range of 10 to $15 \%$ estimated for assumed brucellosis seroprevalence for East Africa [59]. The RBPT test result had supported the evidence that, in sub-Saharan Africa, the highest incidence of brucellosis is observed in pastoral production systems $[6,8,59]$.

Comparable studies have been reported by different scholars in different regions of Ethiopia. A 5\% bovine brucellosis in and around Addis Ababa has been reported by Ethiopian Ministry of Agriculture (1970). According to Yilkal [36], an overall prevalence of $4.6 \%$ has been recorded in and around Addis Ababa. Similarly, Hunduma and Regassa [46] reported $4.1 \%$ in agropastoral areas of East Shoa Zone. Moreover, $4.9 \%$ by Mekonnen et al. [38] in Western Tigray and $4.63 \%$ by Mussie et al. [60] in Bahir Dar milk shed were in tandem with the present finding. In national context, studies conducted in other four African were in tandem with present record. $5.6 \%$ prevalence in Uganda by Faye et al. [61]; 6.5\% in Tanzania by Kagumba and Nandokha [62]; 5.8\% in Nigeria by Cadmus et al. [63]; and $5.9 \%$ in Southern Sudan by Hellman et al. [64] were recorded. 
The present study has revealed higher prevalence than some previous studies. Studies lower than the present report included $1.38 \%$ by Degafu et al. [65] in Jigjiga zone of Somali region, $1.92 \%$ by Asmare et al. [66] in Sidama zone, 3.5\% by Megersa et al. [47] in South Eastern Ethiopia, 1.97\% by Yohannes et al. [41] in Guto-Gida district of East Wollega Zone, $2.9 \%$ by Jergefa et al. [67] in central Oromia, $0.77 \%$ by Tolosa et al. [31] in Jimma, 3.19\% by Berhe et al. [44] in Tigray region, $1.2 \%$ by Haileselassie et al. [68] in Tigray region, and $0.61 \%$ by Belihu [69] in Jimma have been documented.

The higher prevalence observed in the present study could be due to related to pastoral community patterns characterized by clustering of households with their herds in camps, diversity of livestock species reared as part of coping mechanism for uncertainties and risks increase the aggregation and interaction of different animals at villages, herd size, pasture fields, and water points facilitating the transmission of the disease. The frequent migration of pastoral herds might increase the chance of coming into contact with other potentially infected herds in different neighboring areas [58, 70-73]. According to Hellman et al. [64], large herd size enhances the exposure potential, especially following abortion increasing contact in common feeding and watering points promoting transmission of Brucella organisms.

In contrast, the current CFT test result has been by far much lower than that of the previous reports of $38.7 \%$ by Rashid [74] in and around Addis Ababa, 18.4\% by Bekele et al. [71] in selected farms and ranches in South Eastern Ethiopia, 24.1\% by Mekonnen et al. [38] in Western Tigray, $11 \%$ by Kebede et al. [30] in smallholder farms in central Ethiopia, 33\% by Corbel [75], 16.8\% by Bayleyegn [34] in Arsi region, $14.2 \%$ by Taye [76] at Abernosaranch, $18.4 \%$ by Gebremariam [77] with in the dairy farms of around Addis Ababa, 19.5\% by Yirgu [78] in East Shoa Ethiopia, and 16.9\% by Abeje [79] in and around Bahir Dar.

On the continental scale, higher prevalence had also been reported in other African countries including $46.8 \%$ in Uganda by Kungu et al. [80]; 41\% in Togo by Domingo [81]; and $14.2 \%$ in South Africa by Manhica [82].

The lower prevalence observed in this study could be attributed to the fact that the present study has covered over wide geographic coverage. Moreover, the lower prevalence in the present study would be linked to higher scorching sun pressurizing the survival of the bacterium under such high temperature [26].

The observed disparity in bovine brucellosis prevalence among different regions of Ethiopia could be attributed to various factors including differences in testing protocols, age difference, sex, pregnancy status, geographical difference, animal management practices, reproductive diseases, herd size, sample size, and the serological tests employed that would further accentuate these variations [30, 83].

Among associated factors considered under the present study, only sex was observed to have statistically significant association $(P<0.05)$ with brucellosis occurrence, whereas age and study districts had no statistically significant association with the disease $(P>0.05)$.
The study has indicated that gender has shown statistically significant association with the disease $(P<0.05: 0.036)$. The proportion of male cattle $(8.6 \%)$ was more likely to be seropositive to antibodies of Brucella species than female cattle $(3.7 \%)(\mathrm{OR}=2.484 ; 95 \% \mathrm{CI}$ : $1.061-5.815)$. Specifically, male cattle were 2.484 times more likely at risk compared to female. The current finding was in tandem with Megersa et al. [84] and Kassahun et al. [42]. The higher infection rate of male cattle in the current study could be associated to the fact that male cattle are extensively used for serving females across different herds increasing their chance of contracting the bacterium.

Apparently, an opposite outcome has been reported by different scholars indicating that female cattle were proportionally more positive for the disease compared to males. In studies conducted by Mussie et al. [60] and Asfaw et al. [85], the proportion of female cattle was more than that of males with significant association. The lower infection rate in males in these reports could be related to the fact that male cattle were kept for relatively shorter time duration in breeding herd than females and hence decreasing the chance of exposure in males [30]. Moreover, Radostits et al. [55] have shown that erythritol, a polyhydric acid found in higher concentration in the placenta and fetal fluids of females than in seminal vesicles and testis of males, can be responsible for females being more susceptible than males. More importantly, the stress associated with pregnancy and calving tends to lower immunity of female animals [86], and this might also explain the observed difference.

Unlike gender, origin or study locations were observed to hove insignificant influence on the disease. This finding was in agreement with studies conducted by Akinseye et al. $[44,87]$ supporting the current finding and stated that age did not play a significant role in seropositivity of brucellosis in cattle. The absence of association between the disease and study locations could be due to smaller cattle population during sample collection, good husbandry practices by pastoralists, and good public awareness about the disease.

\section{Conclusion and Recommendations}

Bovine brucellosis is a contagious, zoonotic and economically important bacterial disease of human and animals with global perspective. The disease is responsible for sickness, misery, and economic loss than any zoonotic disease. The present study has come up with a moderate record of $5.7 \%$ by CFT and $11.9 \%$ by RBPT in bovine over the three study districts. Of the three associated factors, only sex has come to be significantly associated with the disease. The current report signals a demand of changing lifestyle and husbandry practices to have more traction by government and the public.

Based on the conclusions given, the following recommendations were forwarded:

Regional brucellosis surveillance needs to be done to control the disease 
Advanced and detailed molecular study of the bacterium needs to be done to identify the circulating strain of Brucella species in the region

Public awareness must be made on brucellosis economic and public health impacts at a larger scale.

Abbreviations
LMA: Livestock marketing authority
RBPT:
CFT: $\quad$ Complement fixation test
PA: $\quad$ Peasant association
OIE: $\quad$ Office International des Epizooties
PFE: $\quad$ Pastoralist Forum Ethiopia
CSA: Central Statistical Agency
FAO:
NGOod and Agriculture Organization
WHO: The Wongovernmental organizations
SPSS:

\section{Data Availability}

The data used to support this study are available from the corresponding authors upon request.

\section{Conflicts of Interest}

The authors declare that they have no conflicts of interest regarding this study.

\section{Acknowledgments}

We would like to express our superb and heartfelt gratitude to Samara University, research and community service office, for full funding of this research. Our gratitude would also go to Afar regional pastoral and agropastoral and district level agriculture offices for great support during sample collection.

\section{References}

[1] B. Ulvevadet and V. H. Hausner, "Incentives and regulations to reconcile conservation and development: thirty years of governance of the Sami pastoral ecosystem in Finnmark, Norway," Journal of Environmental Management, vol. 92, no. 10, pp. 2794-2802, 2011.

[2] CSA, Federal democratic republic of Ethiopia, CSA, Addis Ababa, Ethiopia, 2009.

[3] J. Diamond and G. Guns, The Fates of Human Societies, WW Norton and Company, New York, NY, USA, 1997.

[4] R. L. Willham, "Keynote address at the 1985 annual meeting," Journal of Animal Science, vol. 62, no. 6, pp. 1742-1758, 1986.

[5] G. Pappas, P. Papadimitriou, N. Akritidis, L. Christou, and E. V. Tsianos, "The new global map of human brucellosis," The Lancet Infectious Diseases, vol. 6, no. 2, pp. 91-99, 2006.

[6] E. Schelling, C. Diguimbaye, S. Daoud et al., "Brucellosis and Q-fever seroprevalences of nomadic pastoralists and their livestock in Chad," Preventive Veterinary Medicine, vol. 61, no. 4, pp. 279-293, 2003.
[7] M. P. Franco, M. Mulder, R. H. Gilman, and H. L. Smits, "Human brucellosis," The Lancet Infectious Diseases, vol. 7, no. 12, pp. 775-786, 2007.

[8] J. J. McDermott and S. M. Arimi, "Brucellosis in sub-Saharan Africa: epidemiology, control and impact," Veterinary Microbiology, vol. 90, no. 1-4, pp. 111-134, 2002.

[9] B. Abbas and H. Agab, "A review of camel brucellosis," Preventive Veterinary Medicine, vol. 55, no. 1, pp. 47-56, 2002.

[10] O. K. Kolawole, "The investigation and control of a large-scale community outbreak of brucellosis in Nigeria," Public Health, vol. 93, no. 3, pp. 185-193, 1979.

[11] E. G. Pieracci, A. J. Hall, R. Gharpure et al., "Prioritizing zoonotic diseases in Ethiopia using a one health approach," One Health, vol. 2, pp. 131-135, 2016.

[12] J. Godfroid, H. C. Scholz, T. Barbier et al., "Brucellosis at the animal/ecosystem/human interface at the beginning of the 21st century," Preventive Veterinary Medicine, vol. 102, no. 2, pp. 118-131, 2011.

[13] J. S. Glenn and W. P. Karen, Veterinary Microbiology: Bacterial and Fungal Agents of Animal Diseases, 2005.

[14] D. Fretin, A. Fauconnier, S. Köhler et al., "The sheathed flagellum of Brucella melitensis is involved in persistence in a murine model of infection," Cellular Microbiology, vol. 7, no. 5, pp. 687-698, 2005.

[15] M. M. Baba, S. E. Sarkindared, and F. Brisbe, "Serological evidence of brucellosis among predisposed patients with pyrexia of unknown origin in northern Nigeria," Central European Journal of Public Health, vol. 9, pp. 158-161, 2001.

[16] D. K. Kubuafor, B. Awumbila, and B. D. Akanmori, "Seroprevalence of brucellosis in cattle and humans in the Akwapim-South district of Ghana: public health implications," Acta Tropica, vol. 76, no. 1, pp. 45-48, 2000.

[17] H. L. Smits and M. Kadri, "Brucellosis.Indian," Journal of General Practice, vol. 3, pp. 60-64, 2004.

[18] S. H. Nockler, Tropical Animal Healthp. 358, 2nd edition, Kluwer Academic Publishers, Dordrechet, Netherlands, 1996.

[19] Anonymous, Animal Health Disease Cards. Bovine Brucellosis, http://www.fao.org/ag/againfo/subjects/en/health/ diseases-cards/brucellosi-bo.html, 2007.

[20] O. M. Radostits, C. C. Gay, C. D. Blood, and K. W. Hinchcliff, Veterinary Medicine, Textbook of the Disease of Cattle, Sheep, Pigs, Goats and Horses, pp. 867-882, W.B. Saunders Company Ltd, New York, NY, USA, 2000.

[21] R. L. Walker, "Brucella," in Veterinary Microbiology, D. C. Hirsh and Y. Chung Zee, Eds., pp. 196-203, Blackwell Science, Boston, MA, USA, 1999.

[22] M. Corbel, Brucellosis in humans and animals: FAO, OIE, WHO http://www.who.int/csr/resources/publications/ Brucellosis.pdf, 2006.

[23] J. Rushton, The Economics of Animal Health and Production, CAB International, Oxford, England, 2009.

[24] H. C. Scholz, Z. Hubalek, I. Sedlacek et al., "Brucella microti sp. nov., isolated from the common vole Microtus arvalis," International Journal of Systematic and Evolutionary Microbiology, vol. 58, no. 2, pp. 375-382, 2008.

[25] A. M. Coelho, A. C. Coelho, M. Roboredo, and J. Rodrigues, "A case-control study of risk factors for brucellosis seropositivity in Portuguese small ruminants herds," Preventive Veterinary Medicine, vol. 82, no. 3-4, pp. 291-301, 2007.

[26] M. J. Ducrotoy, W. J. Bertu, R. A. Ocholi et al., "Brucellosis as an emerging threat in developing economies: lessons from Nigeria'," PLoS One, vol. 8, Article ID e3008, 2014.

[27] D. Donev, Z. Karadzovski, B. Kasapinov, and V. Lazarevik, "Epidemiological and public health aspects of brucellosis in 
the republic of Macedonia," Journal of Natural Science, Biology and Medicine, vol. 1, pp. 33-54, 2010.

[28] H. L. Smits, M. P. Franco, M. Mulder, and R. H. Gilman, "Human brucellosis," The Lancet Infectious Diseases, vol. 7, pp. 775-786, 2007.

[29] H. Dinka and R. Chala, "Sero prevalence study of bovine brucellosis in pastoral and agro-pastoral areas of East Showa zone, Oromia Regional State, Ethiopia," American-eurasian Journal of Agricultural and Environmental Science, vol. 6, pp. 508-512, 2009.

[30] T. Kebede, G. Ejeta, and G. Ameni, "Seroprevalence of bovine brucellosis in smallholder farms in central Ethiopia (Wuchale-Jida district)," Revue de Médecine Vétérinaire, vol. 159, pp. 3-9, 2008.

[31] T. Tolosa, F. Regassa, and K. Belihu, "Seroprevalence study of bovine brucellosis in extensive management system in selected sites of Jimma zone, western Ethiopia," Bulletin of Animal Health and Production in Africa, vol. 56, no. 1, pp. 25-37, 2008.

[32] M. Yilma, G. Mamo, and B. Mammo, "Review on brucellosis sero-prevalence and ecology in livestock and human population of Ethiopia," Achievements in the Life Sciences, vol. 10, no. 1, pp. 80-86, 2016.

[33] C. E. Mayer, Report on Veterinary Activity, Institute of Agricultural Research, Ethiopia, 1980.

[34] M. Bayleyegne, "Seroepidemiological survey of bovine brucellosis in ArssiRegion," DVM thesis, Addis Ababa University, DebreZeit, Ethiopia, 1989.

[35] S. Tariku, The Impact of Brucellosis on Productivity in Improved Dairy Herd of Chaffa State Farm, Ethiopia, M.Sc. thesis, FachburgVeterinaemedizin, Berlin, Freiuniversitate, 1994.

[36] A. Yilkal, "The epidemiology of bovine brucellosis in inra and peri urban dairy production system in and around Addis Ababa," Master's thesis, Faculty of Veterinary Medicine, Addis Ababa University, Debrezeit, Ethiopia, 1998.

[37] B. Tekelye, O. B. Kasali, M. Mugrewa, R. G. Sholtens, and Y. Tamirat, "The prevalence of Brucellosis in indigenous cattle in central Ethiopia," Bulletin of Animal Health and Production in Africa, vol. 37, pp. 97-98, 2000.

[38] H. Mekonnen, S. Kalayou, and M. Kyule, "Serological survey of bovine brucellosis in barka and arado breeds (Bos indicus) of western Tigray, Ethiopia," Preventive Veterinary Medicine, vol. 94, pp. 28-35, 2010.

[39] Y. Taddesse, "A survey of bovine Brucellosis in selected areas ofNorthGonder Zone," DVM thesis, Addis Ababa University, Addis Ababa, Ethiopia, 2003.

[40] T. Tadele, "Seroprevalence Study of Bovine Brucellosis and its Public Health Significance in Selected Sites of Jimma Zone," M.Sc. thesis, Addis Ababa University, DebreZeit, Ethiopia, 2004.

[41] M. Yohannes, H. Degefu, T. Tolosa, K. Belihu, C. Ronald et al., "Brucellosis in Ethiopia," African Journal of Microbiology Research, vol. 7, pp. 1150-1157, 2013.

[42] A. Kassahun, P. Shiv, A. Yilkal, G. Esayas, A. Gelagaye et al., "Seroprevalence of brucellosis in cattle and high risk professionals in Sidama zone, southern Ethiopia," Ethiopian Veterinary Journal, vol. 11, pp. 69-84, 2007.

[43] T. Sintaro, "The impact of brucellosis onproductivity in an improved dairy herd of Chaffastatefarm," M.Sc. thesis, FachburgVeterinaemedizin, Frei, Universitate, Berlin,, 1994.

[44] G. Berhe, K. Belihu, and Y. Asfaw, "Seroepidemiological investigation of bovine brucellosis in the extensive cattle production system of Tigray region of Ethiopia," The
International Journal of Applied Research in Veterinary, vol. 5, pp. 65-71, 2007.

[45] N. Ibrahim, K. Belihu, F. Lobago, and M. Bekana, "Seroprevalence of bovine brucellosis and its risk factors in Jimma zone of Oromia Region, South-western Ethiopia," Tropical Animal Health and Production, vol. 42, no. 1, pp. 35-4010, 2010.

[46] D. Hunduma and C. Regassa, "Seroprevalence study of bovine brucellosis in pastoral and agro-pastoral areas of East showa zone, Oromia regional state, Ethiopia," American-Eurasian Journal of Agricultural and Environmental, vol. 6, pp. 508512, 2009.

[47] B. Megersa, D. Biffa, F. Niguse, T. Rufael, K. Asmare, and E. Skjerve, "Cattle brucellosis in traditional livestock husbandry practice in Southern and Eastern Ethiopia, and its zoonotic implication," ActaVeterinariaScandinavica, vol. 53, p. 24, 2011.

[48] E. H. El-Ansary, B. Mohammed, A. A. R. Hamad, and A. G. Karom, "Brucellosis among animals and human contacts in Eastern Sudan," Saudi Medical Journal, vol. 22, pp. 577-579, 2001.

[49] M. K. Omer, E. Skjerve, Z. Woldehiwet, and G. Holstad, "Risk factors for Brucella spp. infection in dairy cattle farms in Asmara, State of Eritrea," Preventive Veterinary Medicine, vol. 46, no. 4, pp. 257-265, 2000.

[50] M. K. Omer, T. Assefaw, E. Skjerve, T. Tekleghiorghis, and Z. Woldehiwet, "Prevalence of antibodies to Brucella spp. and risk factors related to high-risk occupational groups in Eritrea," Epidemiology and Infection, vol. 129, no. 1, pp. 85-91, 2002.

[51] M. Thrusfield, Veterinary Epidemiology, pp. 251-281, Blackwell Science, Oxford, England, 2007.

[52] World Organisation for Animal Health, "Caprine and Ovine brucellosis (excluding Brucella ovis infection)," in Proceedings of the Manual of Standard for Diagnostic Test and Vaccine, pp. 475-489, Paris, France, May 2004.

[53] World Organisation for Animal Health, "Ovine and caprine brucellosis," in Proceedings of the Manual of Diagnostic Tests and Vaccines for Terrestrial Animals, Office International des Epizooties, Paris, France, 2009.

[54] Stata v12.0 StatCorp, Texas. USA, 2015, http://www.stata.com.

[55] O. M. Radostits, C. C. Gay, K. W. Hinchcliff, and P. D. Constable, Veterinary Medicine: A Text Book of the Diseases of Cattle, Sheep, Pigs, Goats and Horsespp. 962-984, Saunders Company, Philadelphia, PA, USA, 10 edition, 2007.

[56] C. H. Mwelwa, Prevalence and Risk Factors of Brucellosis in Commercial Cattle in Zambia, M.Sc. thesis, The University of Zambia, Zambia, East Africa, 2012.

[57] J. Godfroid, C. Saegerman, V. Wellemans et al., "How to substantiate eradication of bovine brucellosis when aspecific serological reactions occur in the course of brucellosis testing," Veterinary Microbiology, vol. 90, no. 1-4, pp. 461-477, 2002.

[58] K. L. Samui, J. Oloya, M. Munyeme, and E. Skjerve, "Risk factors for brucellosis in indigenous cattle reared in livestockwildlife interface areas of Zambia," Preventive Veterinary Medicine, vol. 80, pp. 306-317, 2007.

[59] M. Mangen, M. Otte, J. Pfeiffer, and P. Chilonda, Bovine brucellosis in Sub-Saharan Africa: estimation of seroprevalence and impact on meat and milk off take potential, 2002.

[60] H. Mussie, K. Tesfu, and A. Yilkal, "Seroprevalence study of bovine brucellosis in Bahir dar milk shed, northwestern amhara region," Ethiopian Veterinary Journal, vol. 11, no. 1, pp. 42-49, 2007. 
[61] B. Faye, V. Castel, M. Lesnoff, D. Rutabinda, and S. Dhalwa, "Tuberculosis and brucellosis prevalence survey on dairy cattle in Mbarara milk basin (Uganda)," Preventive Veterinary Medicine, vol. 67, no. 4, pp. 267-281, 2005.

[62] M. Kagumba and E. Nandokha, "A survey of the prevalence of bovine brucellosis in East Africa," ournal of Animal Health and Production, vol. 26, no. 3, pp. 224-229, 1978.

[63] S. I. B. Cadmus, I. F. Ijagbone, H. E. Oputa, H. K. Adesoken, and J. A. Stack, "Serological survey of brucellosis in livestock animals and workers in Ibadan Nigeria," African Journal of Biomedical Research, vol. 9, pp. 163-168, 2006.

[64] E. Hellman, C. Staak, and M. Baumann, "Bovine brucellosis among two different cattle populations in Bahr el Ghazal Province of Southern Sudan," Tropical medicine and parasitology, vol. 35, no. 2, pp. 123-126, 1984.

[65] H. Degefu, M. Mohamud, M. Hailemelekot, and M. Yohannes, "Sero prevalence of bovine brucellosis in agro pastoral areas of Jijjiga zone of Somali National Regional State, Eastern Ethiopia," Ethiopian Veterinary Journal, vol. 15, no. 1, pp. 37-47, 2011.

[66] K. Asmare, Y. Asfaw, E. Gelaye, and G. Ayelet, "Brucellosis in extensive management system of zebu cattle in Sidama zone, southern Ethiopia," African Journal of Agricultural Research, vol. 5, pp. 257-263, 2010.

[67] T. Jergefa, B. Kelay, M. Bekana, S. Teshale, H. Gustafson, and H. Kindahl, "Epidemiological study of bovine brucellosis in three agroecological areas of central Oromiya, Ethiopia," Scientific Technical Review, vol. 28, pp. 933-943, 2009.

[68] M. Haileselassie, K. Shewit, and K. Moses, "Serological survey of bovine brucellosis in barka and arado breeds (Bos indicus) of Western Tigray, Ethiopia," Pakistan Veterinary Journal, vol. 94, no. 1-2, pp. 28-35, 2010.

[69] K. Belihu, Analysis of Dairy Cattle Breeding Practices in Selected Areas of Ethiopia, Ph.D. thesis, Humboldt University, Berlin, Germany, 2002.

[70] K. Asmare, "Epidemiology of brucellosis in cattle and its seroprevalence in animal health professionals in Sidama Zone, Southern Ethiopia," M.Sc. thesis, Addis Ababa University, Debre Zeit, Ethiopia, 2004.

[71] A. Bekele, B. Molla, Y. Asfaw, and L. Yirgu, "Bovine brucellosis, sero-epidemiological study in selected farms and ranches in South eastern Ethiopia," Bulletin of Animal Health and Production in Africa, vol. 48, pp. 13-17, 2000.

[72] S. Maiga, M. Traore, M. Niang, and I. Toure, "Seroepidemiological investigation of bovine brucellosis in the dairying belt of Bamako, Mali," in Proceedings of 18th International Conference held at Bamako, Harare, Zimbabwe, January 1996.

[73] T. Tolosa, Sero prevalence study of bovine brucellosis and its public health significance in selected sites of Jimma zone western Ethiopia, FVM, AAU, debre-zeit, Ethiopia, 2004.

[74] M. Rashid, "Reproductive wastage in cattle due to bovine brucellosis," in Proceedings of the 4th Livestock Improvement Conference, pp. 270-272, Ethiopian Institute of Agricultural Research, Addis Ababa, Ethiopia, November 1993.

[75] M. J. Corbel, Brucellosis in Humans and animals, Food and Agriculture Organization and World Organisation for Animal Health, Rome, Italy, 2000.

[76] Y. Taye, Sero prevalence of bovine brucellosis at Abernosaranch. Ethiopia DVM ?esis FVM AAU debre zeit Ethiopia, 1991.

[77] K. Gebremariam, "Prevalence of brucellosis in four different farms around Addis Ababa," DVM thesis, Addis Ababa university, Addis Ababa, Ethiopia, 1985.
[78] T. Yirgu, Seroepidemiological Survey of Bovine Brucellosis at Abernosa, DVM thesis, Addis Ababa University, Debrezeit, Ethiopia, 1991.

[79] S. Abeje, Sero epidemiological study of bovine brucellosis in and around Bahir Dar. DVM Hesis FVM AAU Debre Zeit Ethiopia, 1994.

[80] J. M. Kungu, J. Okwee-Acai, C. Ayebazibwe, S. G. Okech, and J. Erume, "Sero-prevalence and risk factors for brucellosis in cattle in Gulu and Amuru districts, Northern Uganda," Africa Journal Animal and Biomedical Sciences, vol. 5, p. 3, 2010.

[81] A. M. Domingo, "Current status of some zoonoses in Togo," Acta Tropica, vol. 76, no. 1, pp. 65-69, 2000.

[82] P. A. Manhica, The Prevalence of Brucellosis in Cattle, Sheep and Goats in Maputo Province, Mocambique, University of Pretoria, Pretoria, South Africa, 2010.

[83] S. T. Nicolas and A. Khan, "Epidemiology and epizootology of brucellosis: a review," Pakistan Veterinary Journal, vol. 27, pp. 145-151, 2007.

[84] B. Megersa, B. Molla, and L. Yigezu, "Seroprevalence of brucellosis in camels (Camelus dromedarius) in Borena Lowland, southern Ethiopia," Bulletin of Animal Health and Production in Africa, vol. 53, pp. 252-257, 2005.

[85] Y. Asfaw, "The Epidemiology of Brucellosis in Intra and Peri Urban Dairy Production System in and Around Addis Ababa," M.Sc. thesis, Faculty of Veterinary Medicine, Addis Ababa University, Debre Zeit, Ethiopia, 1998.

[86] M. H. Mai, P. C. Irons, and P. N. Thompson, "A large seroprevalence survey of brucellosis in cattle herds under diverse production systems in northern Nigeria," BMC Veterinary Research, vol. 25, p. 8, 2012.

[87] V. O. Akinseye, H. K. Adesokan, A. J. Ogugua et al., "Seroepidemiological survey and risk factors associated with bovine brucellosis among slaughtered cattle in Nigeria," Onderstepoort Journal of Veterinary Research, vol. 83, no. 1, p. a1002, 2016. 